\title{
Quality evaluation of cake prepared by utilizing non- conventional millets of Himachal Pradesh
}

\author{
Shalini Devi and Rajni Modgil
}

The present study was conducted to prepare and evaluate the nutritional quality of millet cake. Millet flours were incorporated at 70 per cent level in cakes and their sensory and nutritional properties were evaluated. The results revealed that, incorporation of millet flours in cake significantly increased the contents of ash (1.27 to 4.32\%), protein (10.45 to $11.13 \%$ ) and fibre (2.18 to 6.95\%). The cake supplemented with Kodra (Eleusine coracana) flour showed maximum overall acceptability after control. From the study it can be concluded that a maximum of 70 per cent millet flours can be incorporated to prepare acceptable quality of cake.

Key Words : Non-conventional millets, Cake, Proximate composition, Sensory acceptability

How to cite this article : Devi, Shalini and Modgil, Rajni (2020). Quality evaluation of cake prepared by utilizing non-conventional millets of Himachal Pradesh. Food Sci. Res. J., 11(2): 130-133, DOI : 10.15740/HAS/FSRJ/11.2/130-133.Copyright@ 2020: Hind Agri-Horticultural Society. 